\title{
Investigating the interplay between transport, land use and the environment: a review of the literature
}

\author{
T. Yigitcanlar $\cdot$ M. Kamruzzaman
}

Received: 18 June 2014/Revised: 11 October 2014/ Accepted: 14 October 2014/Published online: 5 November 2014 (C) Islamic Azad University (IAU) 2014

\begin{abstract}
Integration of land use and transport decisions to achieve sustainable travel behavior has been considered an integral element for sustainable urban development. However, before the popularity of urban sustainability concept, land use and transport interaction had been scrutinized as strictly separate entities in the urban planning and development domains. Fortunately, today the concept of sustainability has been pushed to the forefront of policy-making and politics as the world wakes up to the impacts of climate change and the effects of the rapid urbanization and modern urban lifestyles. The paper therefore aims to highlight the importance of the interplay between transport, land use and the environment. This review paper provides evidence from the literature including the Transport, Land Use and the Environment Special Issue contributions and global best practice cases to showcase new empirical approaches and investigations from different parts of the world that contribute to the wealth of knowledge in exploring the interplay between transport, land use and the environment thoroughly.
\end{abstract}

Keywords Transport · Land use - Environment . Climate change Sustainable urban development . Sustainability

T. Yigitcanlar $(\varangle) \cdot$ M. Kamruzzaman

School of Civil Engineering and Built Environment,

Queensland University of Technology, 2 George Street,

Brisbane, QLD 4001, Australia

e-mail: tan.yigitcanlar@qut.edu.au

\section{Introduction}

This Special Issue on Transport, Land Use and the Environment contains state-of-the-art empirical research focusing on the interplay between transport, land uses and the environment. Each of these sectoral themes is tied together and scrutinized through the sustainability (Naess 2001; Doughty and Hammond 2004; Dovers 2005; Cheng and $\mathrm{Hu}$ 2010) and sustainable urban development (Berke and Conroy 2000; Wheeler and Beatley 2004; Farr 2012) lenses. Although the terms sustainability and sustainable urban development-along with sustainable transport (Black et al. 2002)—have gained international attention for quite a while now, progress on policies for sustainable outcomes in cities, in terms of reducing the ecological footprint of air [e.g., greenhouse gas (GHG) emissions], water and soil pollution, is still in infancy (Stead and Geerlings 2005; Peptenatu et al. 2011; Dizdaroglu et al. 2012). The emission of GHGs (e.g., carbon dioxide, nitrous oxide, water vapor and methane) is considered by most scientists to be a major cause of observed climate change (Bulkeley and Betsill 2005; Hennicke 2005; De Coninck et al. 2008; Hamin and Gurran 2009). Again, among the GHGs, carbon dioxide $\left(\mathrm{CO}_{2}\right)$ is considered the most harmful in terms of contribution to global climate change (Brand and Preston 2010; While et al. 2010). In contrast, transport and land uses are the two major sectors that contribute most in emitting $\mathrm{CO}_{2}$ in the environment, which has led this Special Issue to focus on a joint investigation of the sectors. Moreover, sustainability requires that policymaking for urban travel to be viewed in a holistic sense that planning for transport, land use and the environment no longer be undertaken in isolation one from the other (Van de Walle et al. 2004; Stead and Geerlings 2005; Sessa 2007; Maoh and Kanaroglou 2009). 
Global transport emissions contributed to $24 \%$ of direct $\mathrm{CO}_{2}$ emissions in 2010 and $75 \%$ of global transport emissions were due to road transport (Marsden and Rye 2010; Mahbub et al. 2011; Zhao et al. 2013). More specifically, $12 \%$ of global $\mathrm{CO}_{2}$ is produced from the personal road transport sector and is the only sector in which this trend is increasing (Meyer et al. 2007; Wadud et al. 2008; Hickman et al. 2010). More importantly, the share is expected to grow at a rate of $1.7 \%$ per year up to 2030 . The annual growth rates of $\mathrm{CO}_{2}$ emissions by the transport sector in the developing world and in economies in transition are projected to be even higher, namely 3.4 and $2.2 \%$, respectively (Grazi et al. 2008). As a result, the reduction of $\mathrm{CO}_{2}$ emissions from the transport sector has been identified as a major challenge (Chapman 2007; Hickman et al. 2010). In the USA, around $97 \%$ of the transport emitted GHGs are generated from the combustion of fossil fuels. Sectoral energy utilization patterns in Australia show that the highest energy consumer is the transport sector (42\%) followed by manufacturing (30\%), and commercial and residential (19\%) (BREE 2013). Similar pattern has been reported in the UK (Hickman and Banister 2007). A projected pattern also exhibits that these trends will remain the same in the next four decades. Note again that, a large portion (63\%) of the transport energy is consumed due to household activities (e.g., passenger movement) (Che and Pham 2012). Given that most of the transport energy is coming from non-renewable sources, transport sector is not only contributing to climate change through emitting GHGs, but also the world is expected to face immense energy deficiencies in future (Kerr 1998; Williams and Alhajji 2003; Meehl et al. 2007).

Unlike transport sector, which contributes directly to environmental degradation, land use (or urban form) has both direct and mediating impacts on the environment (Handy 2005; Dhakal 2010). Directly, a change in land use pattern (e.g., from vegetation to urban) is a major factor of climate change (Shaw 1992; Dale 1997; Pena et al. 2007; Watson et al. 2000). Indirectly, urban form influences the way people travel and thereby the level of $\mathrm{CO}_{2}$ emissions. Numerous studies have shown that people living in areas with high residential and/or employment density, diverse land uses (e.g., mix of residential, commercial, recreational, etc.), well-connected street networks (e.g., grid or semi-grid street systems as opposed to cul-de-sacs), with a higher level of public transport accessibility are associated with low $\mathrm{CO}_{2}$ emissions (Cervero and Sullivan 2011; Li 2011; McCormack and Edwards 2011). This is due to the fact that people living in this type of compact neighborhoods tended not to use car frequently, but they are more likely to use transit services. Although both public transport and car are motorized transport and emit GHGs through the combustion of fossil fuel, the average emissions per passenger are far lower in public transport when compared to the car. In addition, such compact neighborhoods limit the number of motorized trips and facilitate trips on foot (zero emitters). The reasons put forward for the above linkages between urban form and travel behavior is that high density generates more passengers to support frequent transit services (Lin and Gau 2006). Mixed land uses provide opportunities for people to live closer to services, facilities and employment and can generate transit trips throughout the day (The City of Calgary 2004). In addition, transit supported uses (e.g., shops) are high pedestrian generators that directly promote greater transit ridership and provide opportunities for multi-purpose trips (Cervero 1996). Street connectivity facilitates walking by reducing walking time from transit stops to opportunities (destinations) or between opportunities.

Note, however, that the relationships between transport and the environment or between land use and the environment is not always unidirectional rather it is more complex and interdependent (Lambin et al. 2003; Koomen and Stillwell 2007; Kamruzzaman et al. 2014). For example, an unprecedented heat wave in the summer of 2010 caused several travel disruption in the USA. McCormack and Edwards (2011) noted that passengers were trapped for more than $4 \mathrm{~h}$ in a metro in Washington D.C, because of heat-warped rails and heatdamaged overhead electrical lines. Similarly, for example, a change in land use pattern (e.g., deforestation) is likely to affect the climate whereas any climatic changes (e.g., excessive temperature) are also likely to alter the land use pattern (e.g., deforestation) of an area. Despite the extent of the impact of climate change has been debated in the literature, researchers all over the world agreed that climate change has a detrimental effect on cities (Koetse and Rietveld 2009; Reddy and Assenza 2009). More importantly, speculation prevails that transport systems have much less adaptive capacity than other city systems. Once transport infrastructures are built, in particular, airports, ports, railways, highways and main roads, they are hard to change. As a result, empirical research is critical to inform policy development in two ways: First, to understand best practices of the development-related transport infrastructure and land uses (e.g., high frequency transport services together with high density land uses) that minimize the impacts on the climate; and second, to comprehend the susceptibility of these practices to minimize climatic disruption and increasing their resiliency. This is particularly necessary in the face of global financial crisis when firms are looking for alternative business models to maximize profits. As a result, attention must be paid so that the new businesses are aligned with the worldview of sustainability-e.g., the 
development and utilization of green technologies, and the promotion of sustainable behavioral changes (Pezzey 2004; Gasparatos et al. 2008).

\section{Materials and methods}

Policy interventions aimed at reducing the transport/land use impacts on the environment can be classified into push (e.g., travel behavioral changes by reducing the attractiveness of the car through higher taxes) and pull (e.g., travel behavioral changes by improving the attractiveness of public transport services by lowering fares and designing walkable roads) measures (Cools et al. 2009; Kamruzzaman et al. 2013). These measures can again be classified as soft or psychological (e.g., campaign, individualized travel planning, teleworking and car pooling) and hard/structural (i.e., modification in infrastructure or legislation) interventions (Department for Transport 2009; Graham-Rowe et al. 2011). Although the effectiveness of such interventions has been assessed in various contexts, they are sporadic in nature. In addition, the assessment of the impacts of the climate on transport and land uses has received little attention from researchers. This review paper conducts a systematic literature search on these topics, which are classified under different sub-headings and reviewed in order to provide a general understanding to the readers on the topics of interest. Note, however, that this review is not comprehensive to cover all articles on the topics rather the literature search was limited to only one database-ScienceDirect in this case. Again, the search focused only on journal articles published from 1990 and onwards. The search was initiated with transport keyword which was subsequently refined stepwise with the keywords "land use," "environment," "sustainability," "sustainable urban development," "sustainable transport," "climate change," "global warming," and "cobenefits". This resulted in over 200 articles on these topics. These abstract of the articles were read first and if this initial review found an article relevant for the Special Issue then it was kept for detailed review.

\section{Results and discussion}

Literature review

Energy and climate policies are often conflicting in nature (Peterson and Rose 2006). Therefore, there is an urgent need for balanced win-win scenarios in developing new policies so that we meet the clean energy demand with no negative impacts on the environment and climate (Simon et al. 2012). The increasing importance of road transport in the overall GHG emissions has led to the adoption of diverse policies for the mitigation of global warming. These policies focus in two directions, depending on whether they involve the reduction of emissions or the mitigation through $\mathrm{CO}_{2}$ sequestration (Pérez-López et al. 2013). This review focuses on the reduction of emissions aspect rather than carbon sequestration.

\section{Impacts of transport and land uses on the environment: models}

Almost all of the studies that have assessed the risk and impact of policy scenarios have used different modeling frameworks. This has led researcher to develop stand-alone software packages containing the models to help ease decision-making. Models play a major role in making long-term forecasts in transport sector. Land use and transport interaction models have been developed extensively since the 1960s. Traditional models were transport and land use integration-the recent global environmental concerns have been incorporated, adding another dimension of "the environment" into the land use transport modeling system (Gu and Young 1998). It is beyond the scope of this article to describe all models used to make the forecasts. One of the earliest models used to assess the environmental impacts of transport is the well-known LUTE (Land Use-Transport-Environment) formulation (Moore-Ii and Kim 1995). Other commonly used models included FACTS (Van Wee et al. 1998), Transportation and Environment Strategy Impact Simulator (TRESIS) (Hensher and Tu 2002), Wellington Integrated Land Use-Transport-Environment Model (WILUTE) (Zhao et al. 2013), Background, Road and Urban Transport modeling of Air quality Limit values (BRUTAL) (Oxley et al. 2012), Land Use Public Transport and Accessibility Index (LUPTAI) (Yigitcanlar et al. 2007a), Integrated Land use Transport Indexing Model (ILTIM) (Dur and Yigitcanlar 2014; Dur et al. 2014) and Micro-level Urban ecosystem Sustainability Indexing Model (MUSIX) (Dizdaroglu and Yigitcanlar 2014; Yigitcanlar et al. 2014). These models have been used to test different policy scenarios as discussed in the following section.

$\mathrm{CO}_{2}$ emission reduction: technological efficiency versus behavioral change

Policy emphasis has been placed on both technical efficiency of the vehicles used to travel (e.g., low carbon car/ fuel) and a behavioral change from car use to more sustainable transport options (e.g., walking, cycling and public transport) in order to reduce the level of $\mathrm{CO}_{2}$ emissions (Anable et al. 2012). Stanley et al. (2011) developed six key policy scenarios in the Australian context and modeled their effectiveness. The scenarios included: 
1. Reduce urban car kilometers travelled;

2. Increase the share of urban trips performed by walking and cycling;

3. Increase public transport's mode share of urban motorized trips;

4. Increase urban car occupancy rates;

5. Reduce forecast fuel use for road freight, and;

6. Improve vehicle efficiency.

Their results show that a very substantial reduction in vehicle emission intensity is absolutely vital to make a major in road transport GHG emissions in Australia. Pérez-López et al. (2013) have indicated that technological improvement requires a drastic change in the fleet to obtain substantial decrease in emission level. In addition to the technological enhancement in vehicle industry, the need for the development of new energy sources and improvements in information technology are also necessary (Woodcock et al. 2007). Creutzig et al. (2011) evaluate the effectiveness and efficiency of alternative fuels and technologies. They concluded that price-based policies and a cap on total emissions are essential for alleviating rebound effects and perverse incentives of fuel efficiency standards and low carbon fuel standards. Stanley et al. (2011), however, acknowledge that technological enhancement must be developed in tandem with major behavioral changes to meet the GHG emission reduction targets in Australia. Similarly, researchers around the world have agreed that only the technology-oriented changes are not sufficient to reduce transport-related carbon emissions without accompanying behavioral change (Oxley et al. 2012). For example, Like Stanley et al. (2011), Hickman and Banister (2007) modeled different scenarios in the UK and found that a $60 \% \mathrm{CO}_{2}$ reduction target (in 2030) can only be achieved by a combination of strong behavioral change and strong technological innovation. However, they concluded by stating that it is in travel behavior that the real change must take place, and this should be implemented now. A danger with the reliance on technological innovations only is that people tend to drive more with the increasing efficiency of vehicles/ fuels and thereby has a rebound effect on the total emission level (Kelly et al. 2009). Most popular policy interventions aimed at changing behavior include: workplace travel plan, station area plan, school travel plan, personalized travel planning, travel awareness campaigns, public transport information and marketing, car clubs and car sharing, and teleworking (Department for Transport 2004, 2009).

It should be noted here that the behavioral shift program could be most effective in cases where they are undertaken with the land use planning policies. This is due to the fact that there is a clear link between land use and transport demand, and therefore, there is a need to issue planning guidance that aims to limit the traffic generation potential of new development (Sorrell 1992). For example, unlike greenfieldbased development in the UK, the land use policy has been reinforced in the last decade with a substantial increase in the share of dwellings built on brownfield land (from $54 \%$ in 1996 to $72 \%$ in 2006), and density of new dwellings-i.e., 25 to 41 dwellings per hectare over the same period (Mitchell et al. 2011). In a study in the Netherlands, Grazi et al. (2008) found that locations where density is 500 addresses per square kilometer higher, $\mathrm{CO}_{2}$ emissions from transport are on average $15 \%$ lower. In addition, cities require safe and pleasant environments for active transport (zero emitters) with destinations in easy reach. Woodcock et al. (2007) have mentioned that much investment in major road projects does not meet the transport needs of poor people, especially women whose trips are primarily local and off road. Sustainable (urban) development is better promoted through improving walking and cycling infrastructures, increasing access to cycles, and investment in transport services for essential needs. It is also worth noting that changes in the built environment rarely have immediate impact rather they largely become effective in the medium term-e.g., over 10-15 years (Hickman and Banister 2007).

\section{Co-benefits of climate policies}

Climate policies often do not get approval due to their high cost involvement in relation to directly observable benefits associate with them. The co-benefits approach can be a way forward for efficient and effective allocation of resources to solve multiple environmental problems. Research has shown that policies to promote access to nonpolluting and sustainable sources of energy (e.g., bio-fuels) have great potential both to improve public health and to mitigate (prevent) climate disruption (Haines et al. 2007). Similarly, the construction of walkable neighborhoods not only helps reduce $\mathrm{CO}_{2}$ emissions but also help to improve health and equity (Woodcock et al. 2007). In a comparative study between London and Delhi, Woodcock et al. (2009) have shown that a reduction in carbon dioxide emissions through an increase in active travel had larger health benefits per each million population (e.g., 7,332 disabilityadjusted life-years in London, and 12,516 in Delhi in a year). 


\section{Environmental management}

Investigating the interplay between transport, land use and the environment also requires focusing on environmental management. Environmental management is a critical process that local authorities, industries, companies and individuals undertake to regulate and protect the health of the natural environment within or outside the urban areas (Khanna and Speir 2013). In most cases, it does not actually involve managing the environment itself, but rather is the process of taking steps and promoting behaviors that will have a positive impact on how environmental resources are used and protected (Mitchell 2013). Historically, the pollution control efforts expended by regulated industrial facilities have focused on the installation and operation of end-of-pipe treatment technologies; however, as environmental protection efforts have matured, environmental protection agencies have begun to explicitly promote the use of pollution prevention management approaches that frequently involve the design and implementation of informal and formal environmental management systems - such as the European Union promotes its Eco-Management and Audit Scheme program for certifying environmental management systems (Earnhart 2013). The positive role that environmental management plays in sustainable development is inevitable and extensively discussed in the literature (see Comoglio and Botta 2012; Schoenherr 2012; Brouhle and Harrington 2014; Ghai and Vivian 2014). Besides, at present the technological advancements in the automotive industry, such as fuelefficient car engines and electric motor vehicles, are among the promising developments for minimizing the environmental externalities along with the effective environmental management policies and actions (Van Vliet et al. 2011; Bellekom et al. 2012).

\section{Specific research and policy challenges ahead}

Economic growth in emerging economies has been identified to be a major threat to the implementation of car reduction policies. Rapid increase in urban population, expansion of middle class in urban centers and availability of cheaper vehicles in developing countries such as in India, the demand for energy and associated emissions from cities are expected to grow rapidly. In contrast, climate change mitigation is not the priority for these economies rather they have other priority areas in policy including local economic growth and development and service delivery (Dulal and Akbar 2013). In contrast in the developed world, for example, in the UK, Argyriou et al.
(2012) have identified that the main barriers toward taking greater local action to reduce greenhouse gases are: lack of time, lack of resources and difficulties in engaging with the wider community. They have also shown that the sharing of knowledge between local authorities is an effective way of encouraging stronger local action on climate change. Lack of coordination and lack of capacity in different government bodies have also been identified to be the main barriers to the implementation of a co-benefits approach (Jiang et al. 2013). As stressed by Dur and Yigitcanlar (2014), integration of land use and transport decisions to achieve sustainable travel behavior is considered an integral element for sustainable urban development, and it would not be correct to state that before the popularity of urban sustainability concept, land use and transport interaction had been scrutinized as strictly separate entities in planning (also see Stead and Marshall 2001; Rassafi and Vaziri 2005). Despite the emphasis of various documents on policy integration and a sizeable academic literature on policy integration, albeit spread across a variety of academic disciplines, research concerning the integration of land use planning, transport and environment policies is relatively scarce and evidence of any translation of rhetoric or theory into practice is difficult to find (Stead and Geerlings 2005).

Lastly, while the interplay between transport and land use are being placed under the microscope, wide range of issues should be considered other than what we have already focused on so far in this paper. These issues include but not limited to the impact of visitors and tourism activities on the environmental quality in major tourism destinations (Majumdar et al. 2013), the effects of infrastructure systems on the environment other than of transportation infrastructure such as waste management systems (Zaman 2013), and the threats of transport systems and urbanization patterns on the pollution of natural resources other than air such as water basins and soil (Parmar and Bhardwaj 2013).

\section{Special issue}

This Special Issue of the International Journal of Environmental Science and Technology on Transport, Land Use and the Environment, along with this Editorial piece that is written in the format of a literature review paper, consists of the following 23 papers focusing on complementary aspects of the empirical transport, land use and the environmental investigation. The guest editors have selectively identified and invited authors to make submission to the Special Issue, where the papers underwent a standard 
independent double blind and editorial review before final decision was made. The papers contained in this Special Issue represent the latest research in the field and compliments the literature review presented in this editorial piece. The research reported in these papers focuses on empirical research from 12 different countries-i.e., Australia, USA, Turkey, Greece, Brazil, Germany, Northern Ireland, India, Portugal, China, Korea and Canada. Collectively we hope this collection of papers, which provide rich and diverse perspectives on the topic, will function as an acknowledgment of the centrality of empirical transport, land use and the environmental research for our cities to achieve a sustainable urban development, bridge the research gap and shed light on the new empirical directions in this important research field.

1. Investigating the interplay between transport, land use and the environment: a review of the literature

2. Australian baby boomers switched to more environmentally friendly modes of transport during the global financial crisis

3. Impacts of high intensity storms on urban transportation: applying traffic flow control methodologies for quantifying the effects

4. Emission factors of air pollutants from vehicles measured inside road tunnels in Sao Paulo: case study comparison

5. The potential of carbon dioxide emission reductions in German commercial transport by electric vehicles

6. The impact of telecommuting on personal vehicle usage and environmental sustainability

7. Analysis of interaction among land use, transportation network and air pollution using stochastic nonlinear programming

8. Identifying the underlying constructs linking urban form and travel behavior using a grounded theory approach

9. Evaluating the dynamic impacts of urban form on transportation and environmental outcomes in U.S. cities

10. Alternative and adaptive transportation: what household factors support recovery from a drastic increase in gas price?

11. Evaluation of heavy metal and total petroleum hydrocarbon contamination of road side surface soil

12. Managing cost implications for highway infrastructure sustainability

13. Ecological valuation in a transportation project: value transfer and spatial decision support systems

14. The influence of street environments on fuel efficiency: insights from naturalistic driving
15. Traffic air pollution monitoring based on an air-water pollutants deposition device

16. Correlation between optimal carsharing locations and carbon dioxide emissions in urban areas

17. Influence of traffic characteristics on polycyclic aromatic hydrocarbon build-up on urban road surfaces

18. Impact of ubiquitous computing technologies on changing travel and land use patterns

19. Oil vulnerability in the Greater Toronto Area: impacts of high fuel prices on urban form and environment

20. A bid-rent land use adaption model for mitigating road network vulnerability and traffic emissions

21. Challenges to active transport in a car-dependent urban environment: a case study of Auckland, New Zealand

22. Highway freight transportation disruptions under an extreme environmental event: the case of Hurricane Katrina

23. Near-road fine particulate matter concentration estimation using artificial neural network approach

Following the findings from the literature review and this brief editorial introduction (Paper 1: Investigating the interplay between transport, land use and the environment: a review of the literature) by the guest editors, the Special Issue starts with a Position Paper by Md. Kamruzzaman, Tan Yigitcanlar, Simon Washington, Graham Currie and Gavin Turrell (Paper 2: Australian baby boomers switched to more environmentally friendly modes of transport during the global financial crisis). The paper investigates the travel behavior impacts of the 2008 global financial crisis in Brisbane, Australia and discusses the broader implications on the environment.

Next in Paper 3, Evangelos Mitsakis, Iraklis Stamos, Michalis Diakakis and Josep Maria Salanova Grau (Impacts of high intensity storms on urban transportation: applying traffic flow control methodologies for quantifying the effects) scrutinize and quantify storm's impacts on vehicular traffic in terms of operational disruptions by analyzing various traffic-related indicators and using data from the Athens, Greece traffic management center and urban freight vehicle fleets.

Paper 4 by Pedro Jose Perez-Martinez, R.M. Miranda, T. Nogueira, M.L. Guardani, A. Fornaro, R. Ynoue and M.F. Andrade (Emission factors of air pollutants from vehicles measured inside road tunnels in Sao Paulo: case study comparison) offers an analysis approach for the measurement of air pollutants for a mixed vehicle fleet, heavy and 
light duty vehicles, in the tunnels of the Metropolitan Region of Sao Paulo, Brazil in order to accurately calculate the pollutant emission factors.

In Paper 5 (The potential of carbon dioxide emission reductions in German commercial transport by electric vehicles), Thomas Ketelaer, Thomas Kaschub, Patrick Jochem and Wolf Fichtner focus on the analysis of the commercial transport in Germany with an aim of identifying appropriate economic sectors for electric mobility. Based on German survey data, the paper analyzes the heterogeneous German economic sectors with top-down statistical and bottom-up values.

In turn, Pengyu Zhu and Susan G. Mason in Paper 6 (The impact of telecommuting on personal vehicle usage and environmental sustainability) deal with the linkages between telecommuting and environmental sustainability. The paper aims to explore whether telecommuting could be part of the policy solutions for greenhouse gas reduction in transportation sector in the case of the USA, and whether telecommuting reduces or increases the daily work and non-work vehicle miles traveled.

Next, Narges Shahraki and Metin Turkay offer Paper 7 (Analysis of interaction among land use, transportation network and air pollution using stochastic nonlinear programming). This paper formulates stochastic bi-objective optimization models to analyze interaction among land use, transportation structure and amount of air pollution and generates useful insights on the relationship among land use, transportation network and environmental impact associated with them.

Then, in Paper 8 (Identifying the underlying constructs linking urban form and travel behavior using a grounded theory approach), Urbi Banerjee and Julian Hine aim to investigate the relationship between urban form and travel behavior. Authors, using a grounded theory analysis, report the findings from focus-group discussions and in-depth interviews, from three case study areas across Northern Ireland. They come up with seven overarching categories explaining the inter-relationships between urban form and travel behavior.

Paper 9, (Evaluating the dynamic impacts of urban form on transportation and environmental outcomes in U.S. cities), by Shakil Bin Kashem, Andi Irawan and Bev Wilson, hypnotizes that the impacts of urban sprawl are dynamic rather than static and are accelerated in more sprawling cities relative to less sprawling cities. Authors put this hypothesis into test in the USA with a hybrid modeling framework that incorporates fixed and random effects to evaluate different transportation and environmental outcomes over time.
Paper 10 (Alternative and adaptive transportation: what household factors support recovery from a drastic increase in gas price?), by Rachael Bronson and Wesley Marshall, aims to investigate how geographically and demographically diverse areas in Denver, Colorado, USA are affected by a disruptive event such as a gas price increase and measure the financial benefit and resiliency value of various multi-modal transportation infrastructures and how these investments support vulnerable communities.

Anisa Basheer Khan and Srujana Kathi, in Paper 11 (Evaluation of heavy metal and total petroleum hydrocarbon contamination of road side surface soil), examine urban soils that are marked with elevated levels of heavy metals due to extensive anthropogenic activities related to vehicular emissions and traffic. Their investigation takes place along three major highways of Puducherry, India. The findings contribute to our understanding in the measurement of near-road pollution and its impact on the environment.

Next in Paper 12 (Managing cost implications for highway infrastructure sustainability), Kai Chen Goh and Jay Yang investigate the current practice of lifecycle cost analysis, and the identification and quantification of sustainability-related cost components in highway projects. The paper provides a platform for highway project stakeholders to develop practical tools to evaluate highway investment decisions and reach an optimum balance between financial viability and sustainability deliverables.

The author (Hwan Yong Kim) of Paper 13 (Ecological valuation in a transportation project: value transfer and spatial decision support systems) researches to address two critical research questions related to the ecological valuation in transportation projects. The paper aims to answer these questions through the spatial decision support system and ecosystem valuation approaches applied in the case of route alternatives between Austin and Houston Texas, USA airports.

Then in Paper 14 (The influence of street environments on fuel efficiency: insights from naturalistic driving) Xiaoguang Wang, Chao Liu, Lidia Kostyniuk, Qing Shen and Shan Bao address, through applied Structural Equation Modeling, their research question of how driving behaviors and fuel efficiency respond to different street environments. In order to do so authors use a naturalistic driving dataset that recorded detailed driving patterns of drivers randomly selected from the Southeast Michigan Region, USA.

In Paper 15 (Traffic air pollution monitoring based on an air-water pollutants deposition device), Ligia T. Silva, Jose L.S. Pinho and Habib A. Nurusmanindicate pollutant 
emissions by vehicles in urban roads as a major environmental concern and focus their investigation on traffic originated air pollution. They develop and use an air-water surface sampler to evaluate the atmosphere deposition due to the urban traffic air pollution in the business center of Viana do Castelo, Portugal.

Jung-Beom Lee, Wanhee Byun, Sang Hyuk Lee and Myungsik Doin in Paper 16 (Correlation between optimal carsharing locations and carbon dioxide emissions in urban areas) focus their attention on car sharing as a means to alleviate air pollution and traffic congestion. They examine the characteristics of the participants of car sharing in the City of Daejeon, South Korea, in order to determine that city's optimal car sharing service locations and generate insights on how $\mathrm{CO}_{2}$ emissions can be reduced in urban areas.

Paper 17 (Influence of traffic characteristics on polycyclic aromatic hydrocarbon build-up on urban road surfaces), authored by Janaka Gunawardena, Abdul Mohamed Ziyath, Prasanna Egodawatta, Godwin A Ayoko and Ashantha Goonetilleke, explore the linkages between concentrations of pollutants and traffic characteristics such as traffic volume, vehicle mix and traffic flow. In a case exploration from Queensland, Australia authors find the primary source of polycyclic aromatic hydrocarbons on road build-up as traffic activities.

Sang Ho Lee, Youn Taik Leem and Jung Hoon Han in Paper 18 (Impact of ubiquitous computing technologies on changing travel and land use patterns) scrutinizes spatial and temporal changes in land use and intra-urban travel patterns in a highly digital technology driven city type so called Korean ubiquitous cities. Authors employ a cellular automata model to simulate urban land use patterns and a gravity model to estimate trip frequencies. Findings suggest ubiquitous city form decreases the total travel distance and reduces carbon emissions.

Next in Paper 19 (Oil vulnerability in the Greater Toronto Area: impacts of high fuel prices on urban form and environment), by Saidal Akbari and Khandker Nurul Habib, explores the impacts of rising fuel prices on urban areas and advocates sustainable urban transportation planning. They advance the vulnerability index for petrol expense raises framework by incorporating travel survey data to better represent households' car dependence. The model is also put into test in the case of Greater Toronto area, Canada.

Authors (Liyuan Zhao, Zhong-Ren Peng, Fei Yang and Suwan Shen) of Paper 20 (A bid-rent land use adaption model for mitigating road network vulnerability and traffic emissions) aim to consolidate the land use adaptation strategy into transportation vulnerability assessment, quantitatively exploring the question of how to optimize spatial patterns in long-term land use planning to improve network reliability and protect existing vulnerable links and critical locations through a land use adaptation model.

Paper 21, (Challenges to active transport in a cardependent urban environment: a case study of Auckland, New Zealand) by Thomas Robert Faherty, John Edward Morrissey, explores the challenges of achieving active transport in a highly motor vehicle depended environment. Authors present an analysis of stakeholder interview data collected in Auckland. The paper provides an evaluation of approaches taken by the city council to increase rates of active transport and highlights a range of policy instruments, and highlights the challenges.

Subsequently, Paper 22 (Highway freight transportation disruptions under an extreme environmental event: the case of Hurricane Katrina), by Guoqiang Shen and Saniya Gizem Aydin, develops an accessibility-based methodology to identify and prioritize critical transportation infrastructure. The methodology evaluates the network wide impacts of sea-level rise flooding based on the changes in travel cost taking origin importance, destination attractiveness, and traffic congestion into account in Hillsborough County, Florida.

Lastly, the final piece of the Special Issue, Paper 23 (Near-road fine particulate matter concentration estimation using artificial neural network approach) by D. Z. Zhang and Z. R. Peng focuses on the analysis of near-road fine particulate matter concentration and distribution. The paper applies artificial neural network method to estimate particulate matter concentrations, and then the estimated values are compared with values detected from case study cities of Gainesville, Florida and Shanghai, China.

\section{Conclusion}

In the age of globalization, rapid urbanization and climate change, sustainable urban development has become to the forefront of the scholarly discussion to search for remedies to protect environmental degradation (Redclift 2005; Teriman et al. 2009; Rydin 2010; Runhaar et al. 2009; Yigitcanlar and Teriman 2014). With the development of advance technologies mew methods, tools and approaches 
have been developed to shape up the urban space and generate new environmentally friendly place for us to live in harmony with the natural environment-such as ubiquitous-eco-cities of Korea (Yigitcanlar and Lee 2014). At the same time, many academics and decision-makers have appreciated the importance of integrating urban and infrastructure (more particularly transport) development to achieve a more sustainable urban development (Newman and Jennings 2008; Yigitcanlar 2010a, b; Goonetilleke et al. 2014). This lead into development of various methods to assess and measure the integration of transport and land use (Yigitcanlar and Dur 2010; Dur and Yigitcanlar 2014), examine the transport disadvantage levels (Duvarci and Yigitcanlar 2007; Duvarci et al. 2011), analysis of existing travel patterns and trends (Yigitcanlar et al. 2007b; Zhao 2010) and also impacts on the natural environment (Alam et al. 2006; Tuzkaya 2009; Liao et al. 2013). On top of these, the papers of this Special Issue reports new empirical approaches and investigations from different parts of the world that contributes to the wealth of knowledge in investigating the interplay between transport, land use and the environment.

Acknowledgments We wish to thank the authors of the abovementioned 23 papers for accepting our invitation and submitting and revising their manuscripts within a short time frame and thank the referees of these papers for their constructive, thorough and timely reviews. We particularly want to thank the Editor-in-Chief Professor M. Abbaspour of the International Journal of Environmental Science and Technology for inviting us to edit this Special Issue on Transport, Land Use and the Environment. We also cordially thank the Managing Editor Mrs. S. Mirkia for her support and assistance in the preparation of this issue. Lastly, we thank and acknowledge the useful comments and feedback of the reviewers provided for an earlier version of this editorial piece.

\section{References}

Alam J, Alam B, Rahman M, Khan S, Munna G (2006) Unplanned urbanization: assessment through calculation of environmental degradation index. Int J Environ Sci Technol 3(2):119-130

Anable J, Brand C, Tran M, Eyre N (2012) Modelling transport energy demand: a socio-technical approach. Energy Policy 41(1):125-138

Argyriou I, Fleming P, Wright A (2012) Local climate policy: lessons from a case study of transfer of expertise between UK local authorities. Sustain Cities Soc 5(1):87-95

Bellekom S, Benders R, Pelgröm S, Moll H (2012) Electric cars and wind energy: two problems, one solution? Energy 45(1):859-866

Berke P, Conroy M (2000) Are we planning for sustainable development? An evaluation of 30 comprehensive plans. J Am Plan Assoc 66(1):21-33

Black J, Paez A, Suthanaya P (2002) Sustainable urban transportation. J Urban Plan Dev 128(1):184-209

Brand C, Preston J (2010) 60-20 emission: the unequal distribution of green house gas emissions from personal, non-business travel in the UK. Transp Policy 17(1):9-19
BREE (Bureau of Resources and Energy Economics) (2013) Australian energy statistics. BREE, Canberra

Brouhle K, Harrington D (2014) The role of environmental management systems in the Canadian Voluntary Climate and Challenge Registry. J Environ Plan Manage 57(8): $1145-1168$

Bulkeley H, Betsill M (2005) Rethinking sustainable cities: multilevel governance and the urban politics of climate change. Environ Polit 14(1):42-63

Cervero R (1996) Mixed land-uses and commuting: evidence from the American Housing Survey. Transp Res Part A Policy Pract 30(1):361-377

Cervero R, Sullivan C (2011) Green TODs: marrying transit-oriented development and green urbanism. Int J Sustain Dev World Ecol 18(1):210-218

Chapman L (2007) Transport and climate change: a review. J Transp Geogr 15(1):354-367

Che N, Pham P (2012) Economic analysis of end-use energy intensity in Australia. Bureau of Resources and Energy Economics, Canberra

Cheng H, Hu Y (2010) Planning for sustainability in China's urban development: status and challenges for Dongtan eco-city project. J Environ Monit 12(1):119-126

Comoglio C, Botta S (2012) The use of indicators and the role of environmental management systems for environmental performances improvement. J Clean Prod 20(1):92-102

Cools M, Moons E, Janssens B, Wets G (2009) Shifting towards environment-friendly modes: profiling travelers using Q-methodology. Transportation 36(1):437-453

Creutzig F, McGlynn E, Minx J, Edenhofer O (2011) Climate policies for road transport revisited: evaluation of the current framework. Energy Policy 39(1):2396-2406

Dale V (1997) The relationship between land use change and climate change. Ecol Appl 7(1):753-769

De Coninck H, Fischer C, Newell R, Ueno T (2008) International technology-oriented agreements to address climate change. Energy Policy 36(1):335-356

Department for Transport (2004) Smarter choices: changing the way we travel. The UK Government Department for Transport. https:// www.gov.uk/government/publications/smarter-choices-mainreport-about-changing-the-way-we-travel. Accessed 14 Aug 2013

Department for Transport (2009) Delivering sustainable low carbon travel: an essential guide for local authorities. The UK Government Department for Transport. http://www.communityplanning. net/pub-film/pdf/DeliveringSustainableLowCarbonTravel.pdf. Accessed 14 Aug 2013

Dhakal S (2010) GHG emissions from urbanization and opportunities for urban carbon mitigation. Curr Opin Environ Sustain 2(1):277-283

Dizdaroglu D, Yigitcanlar T (2014) A parcel-scale assessment tool to measure sustainability through urban ecosystem components: the MUSIX model. Ecol Ind 41(1):115-130

Dizdaroglu D, Yigitcanlar T, Dawes L (2012) A micro-level indexing model for assessing urban ecosystem sustainability. Smart Sustain Built Environ 1(3):291-315

Doughty M, Hammond G (2004) Sustainability and the built environment at and beyond the city scale. Build Environ 39(10):1223-1233

Dovers S (2005) Environment and sustainability policy: creation, implementation, evaluation. Federation Press, London

Dulal H, Akbar S (2013) Greenhouse gas emission reduction options for cities: finding the "coincidence of agendas" between local priorities and climate change mitigation objectives. Habitat International 38(1):100-105 
Dur F, Yigitcanlar T (2014) Assessing land-use and transport integration via a spatial composite indexing model. Int J Environ Sci Technol. doi:10.1007/s13762-013-0476-9

Dur F, Yigitcanlar T, Bunker J (2014) A spatial indexing model for measuring neighbourhood level land-use and transport integration. Environ and Plan B. doi:10.1068/b39028

Duvarci Y, Yigitcanlar T (2007) Integrated modeling approach for the transportation disadvantaged. J Urban Plan Dev-ASCE 133(3): $188-200$

Duvarci Y, Yigitcanlar T, Alver Y, Mizokami S (2011) The variant concept of transportation disadvantaged: evidence from Aydin, Turkey and Yamaga, Japan. J Urban Plan Dev-ASCE 137(1):82-90

Earnhart D (2013) Effect of systems to manage environmental aspects on environmental performance. Sustainability 5(6):2557-2588

Farr D (2012) Sustainable urbanism: urban design with nature. Wiley, London

Gasparatos A, El-Haram M, Horner M (2008) A critical review of reductionist approaches for assessing the progress towards sustainability. Environ Impact Assess Rev 28(1):286-311

Ghai D, Vivian J (2014) Grassroots environmental action: people's participation in sustainable development. Routledge, New York

Goonetilleke A, Yigitcanlar T, Ayoko G, Egodawatta P (2014) Sustainable urban water environment: climate, pollution and adaptation. Edward Elgar Publishing, Cheltenham

Graham-Rowe E, Skippon S, Gardner B, Abraham C (2011) Can we reduce car use and, if so, how? A review of available evidence. Transp Res Part A Policy Pract 45(1):401-418

Grazi F, Van den Bergh J, Van Ommeren J (2008) An empirical analysis of urban form, transport, and global warming. Energy $\mathrm{J}$ 29(1):97-122

Gu K, Young W (1998) Verifying and validating a land use-transportenvironment model. Transp Plan Technol 21(1):181-202

Haines A, Smith K, Anderson D, Epstein P, McMichael A, Roberts I, Wilkinson P, Woodcock J, Woods J (2007) Policies for accelerating access to clean energy, improving health, advancing development, and mitigating climate change. Lancet 370(1):1264-1281

Hamin E, Gurran N (2009) Urban form and climate change: balancing adaptation and mitigation in the US and Australia. Habitat Int 33(3):238-245

Handy S (2005) Smart growth and the transportation land-use connection. Int Reg Sci Rev 28(2):146-167

Hennicke P (2005) Long-term scenarios and options for sustainable energy systems and for climate protection: a short overview. Int J Environ Sci Technol 2(2):181-191

Hensher D, Tu T (2002) TRESIS: a transportation, land use and environmental strategy impact simulator for urban areas. Transportation 29(1):439-457

Hickman R, Banister D (2007) Looking over the horizon: transport and reduced $\mathrm{CO}_{2}$ emissions in the UK by 2030. Transp Policy 14(1):377-387

Hickman R, Ashiru O, Banister D (2010) Transport and climate change: simulating the options for carbon reduction in London. Transp Policy 17(1):110-125

Jiang P, Chen Y, Geng Y, Dong W, Xue B, Xu B, Li W (2013) Analysis of the co-benefits of climate change mitigation and air pollution reduction in China. J Clean Prod 58(1):130-137

Kamruzzaman M, Baker D, Washington S, Turrell G (2013) Residential dissonance and mode choice. J Transp Geogr 33(1):12-28

Kamruzzaman M, Yigitcanlar T, Washington S, Currie G (2014) Australian baby boomers switched to more environmentally friendly modes of transport during the global financial crisis. Int J Environ Sci Technol. doi:10.1007/s13762-014-0564-5
Kelly J, Ryan L, Casey E, O'Riordan N (2009) Profiling road transport activity: emissions from 2000 to 2005 in Ireland using national car test data. Transp Policy 16(1):183-192

Kerr R (1998) The next oil crisis looms large-and perhaps close. Science 281(1):1128-1131

Khanna M, Speir C (2013) Motivations for proactive environmental management. Sustainability 5(6):2664-2692

Koetse M, Rietveld P (2009) The impact of climate change and weather on transport: an overview of empirical findings. Transp Res Part D Transp Environ 14(1):205-221

Koomen E, Stillwell J (2007) Modelling land-use change. In: Koomen E, Stillwell J, Bakema A, Sholten H (eds) Modelling land-use change: progress and applications. Springer, Dordrecht, pp 1-21

Lambin E, Geist H, Lepers E (2003) Dynamics of land-use and landcover change in tropical regions. Annu Rev Environ Resour 28(1):205-241

Li J (2011) Decoupling urban transport from GHG emissions in Indian cities: a critical review and perspectives. Energy Policy 39(1):3503-3514

Liao C, Chang C, Su C, Chiueh P (2013) Correlation between landuse change and greenhouse gas emissions in urban areas. Int $\mathrm{J}$ Environ Sci Technol 10(6):1275-1286

Lin J, Gau C (2006) A TOD planning model to review the regulation of allowable development densities around subway stations. Land Use Policy 23(1):353-360

Mahbub P, Goonetilleke A, Ayoko G, Egodawatta P, Yigitcanlar T (2011) Analysis of build-up of heavy metals and volatile organics on urban roads in Gold Coast, Australia. Water Sci Technol 63(9):2077-2085

Majumdar D, Chintada A, Sahu J, Rao C (2013) Emissions of greenhouse and non-greenhouse air pollutants from fuel combustion in restaurant industry. Int $\mathrm{J}$ Environ Sci Technol 10(5):995-1006

Maoh H, Kanaroglou P (2009) A tool for evaluating urban sustainability via integrated transportation and land use simulation models. Environ Urbain/Urban Environ 3(1):28-46

Marsden G, Rye T (2010) The governance of transport and climate change. J Transp Geogr 18(1):669-678

McCormack F, Edwards F (2011) Greener transport mitigates climate change. Public Manager 40(1):37-41

Meehl G, Stocker T, Collins W, Friedlingstein P, Gaye A, Gregory J, Zhao Z (2007) Global climate projections. Clim Change 13(1):747-845

Meyer I, Leimbach M, Jaeger C (2007) International passenger transport and climate change: a sector analysis in car demand and associated $\mathrm{CO}_{2}$ emissions from 2000 to 2050. Energy Policy 35(1):6332-6345

Mitchell B (2013) Resource and environmental management. Routledge, New York

Mitchell G, Hargreaves A, Namdeo A, Echenique M (2011) Land use, transport, and carbon futures: the impact of spatial form strategies in three UK urban regions. Environ Plan A 43(1):2143-2163

Moore-Ii J, Kim T (1995) Mills' urban system models: perspective and template for LUTE (Land Use/Transport/Environment) applications. Comput Environ Urban Syst 19(1):207-225

Naess P (2001) Urban planning and sustainable development. Eur Plan Stud 9(4):503-524

Newman P, Jennings I (2008) Cities as sustainable ecosystems: principles and practices. Island Press, Washington, DC

Oxley T, Elshkaki A, Kwiatkowski L, Castillo A, Scarbrough T, Simon H (2012) Pollution abatement from road transport: crosssectoral implications, climate co-benefits and behavioural change. Environ Sci Policy 19-20(1):16-32 
Parmar K, Bhardwaj R (2013) Water quality index and fractal dimension analysis of water parameters. Int $\mathrm{J}$ Environ Sci Technol 10(1):151-164

Pena J, Bonet A, Bellot J, Sanchez J, Eisenhuth D, Hallett S, Aledo A (2007) Driving forces of land-use change in a cultural landscape of Spain. In: Koomen E, Stillwell J, Bakema A, Sholten H (eds) Modelling land-use change: progress and applications. Springer, Dordrecht, pp 1-21

Peptenatu D, Pintilu R, Draghici C (2011) Environmental risk management of urban growth poles regarding national importance. Int J Environ Sci Technol 8(4):737-746

Pérez-López P, Gasol C, Oliver-Solà J, Huelin S, Moreira M, Feijoo G (2013) Greenhouse gas emissions from Spanish motorway transport: key aspects and mitigation solutions. Energy Policy 60(1):705-713

Peterson T, Rose A (2006) Reducing conflicts between climate policy and energy policy in the US: the important role of the states. Energy Policy 34(1):619-631

Pezzey J (2004) Sustainability policy and environmental policy. Scand J Econ 106(2):339-359

Rassafi A, Vaziri M (2005) Sustainable transport indicators: definition and integration. Int J Environ Sci Technol 2(1):83-96

Redclift M (2005) Sustainable development (1987-2005): an oxymoron comes of age. Sustain Dev 13(4):212-227

Reddy B, Assenza G (2009) The great climate debate. Energy Policy 8(1):2997-3008

Runhaar H, Driessen P, Soer L (2009) Sustainable urban development and the challenge of policy integration: an assessment of planning tools for integrating spatial and environmental planning in the Netherlands. Environ Plan 36(3):417-431

Rydin Y (2010) Governing for sustainable urban development. Earthscan, London

Schoenherr T (2012) The role of environmental management in sustainable business development: a multi-country investigation. Int J Prod Econ 140(1):116-128

Sessa C (2007) Achieving sustainable cities with integrated land-use and transport strategies. In: Marshall S, Banister D (eds) Land use and transport: european research towards integrated policies. Elsevier, Amsterdam, pp 37-70

Shaw R (1992) The impact of population growth on environment: the debate heats up. Environ Impact Assess Rev 12(1):11-36

Simon G, Bumpus A, Mann P (2012) Win-win scenarios at the climate-development interface: challenges and opportunities for stove replacement programs through carbon finance. Glob Environ Change 22(1):275-287

Sorrell S (1992) Working together for a better environment: challenges for transport. Energy Policy 20(1):378-379

Stanley J, Hensher D, Loader C (2011) Road transport and climate change: stepping off the greenhouse gas. Transp Res Part A Policy Pract 45(1):1020-1030

Stead D, Geerlings H (2005) Integrating transport, land use planning and environment policy. Innovation: Eur J Soc Sci Res 18(1):443-453

Stead D, Marshall S (2001) The relationships between urban form and travel patterns: an international review and evaluation. Eur $\mathrm{J}$ Transp Infrastruct Res 1(2):113-141

Teriman S, Yigitcanlar T, Mayere S (2009) Urban sustainability and growth management in South-East Asian city-regions: the case of Kuala Lumpur and Hong Kong. Plan Malays $7(1): 47-68$

The City of Calgary (2004) Transit oriented development: best practices handbook. Land Use Plan Policy, Calgary
Tuzkaya U (2009) Evaluating the environmental effects of transportation modes using and integrated methodology and an application. Int J Environ Sci Technol 6(2):277-290

Van de Walle S, Steenberghen T, Paulley N, Pedler A, Martens M (2004) The role of indicators in the assessment of integrated land-use and transport policies in European cities. Int J Plan Stud 9(2-3):173-196

Van Vliet O, Brouwer A, Kuramochi T, van Den Broek M, Faaij A (2011) Energy use, cost and $\mathrm{CO} 2$ emissions of electric cars. J Power Sources 196(4):2298-2310

Van Wee B, Geurs K, Van den Brink R, Annema JA (1998) Transport and the environment: the contribution of national and local policies. Environ Pollut 102:663-670

Wadud Z, Noland R, Graham D (2008) Equity analysis of personal tradable carbon permits for the road transport sector. Environ Sci Policy 11(1):533-544

Watson R, Noble I, Bolin B, Ravindranath N, Verardo D, Dokken D (2000) Land use, land-use change, and forestry: a special report of the intergovernmental panel on climatic change. Cambridge University Press, Cambridge

Wheeler S, Beatley T (eds) (2004) The sustainable urban development reader. Routledge, New York

While A, Jonas A, Gibbs D (2010) From sustainable development to carbon control: ecostate restructuring and the politics of urban and regional development. Trans Inst $\mathrm{Br}$ Geogr 35(1):76-93

Williams J, Alhajji A (2003) The coming energy crisis. Oil Gas J 101(5): $1-13$

Woodcock J, Banister D, Edwards P, Prentice A, Roberts I (2007) Energy and transport. Lancet 370(1):1078-1088

Woodcock J, Edwards P, Tonne C, Armstrong B, Ashiru O, Banister D, Beevers S, Chalabi Z, Chowdhury Z, Cohen A, Franco O, Haines A, Hickman R, Lindsay G, Mittal I, Mohan D, Tiwari G, Woodward A, Roberts I (2009) Public health benefits of strategies to reduce greenhouse-gas emissions: urban land transport. Lancet 374(1):1930-1943

Yigitcanlar T (ed) (2010a) Rethinking sustainable development: urban management, engineering and design. IGI Global, Hersey

Yigitcanlar T (ed) (2010b) Sustainable urban and regional infrastructure development: technologies, applications and management. IGI Global, Hersey

Yigitcanlar T, Dur F (2010) Developing a sustainability assessment model: the sustainable infrastructure land-use environment and transport model. Sustainability 2(1):321-340

Yigitcanlar T, Lee S (2014) Korean ubiquitous-eco-city: a smartsustainable urban form or a branding hoax? Technol Forecast Soc Chang. doi:10.1016/j.techfore.2013.08.034

Yigitcanlar T, Teriman S (2014) Rethinking sustainable urban development: towards an integrated planning and development process. Int J Environ Sci Technol. doi:10.1007/s13762-0130491-x

Yigitcanlar T, Sipe N, Evans R, Pitot M (2007a) A GIS-based land use and public transport accessibility indexing model. Australian Plan 44(3):30-37

Yigitcanlar T, Dodson J, Gleeson B, Sipe N (2007b) Travel selfcontainment in master planned estates: analysis of recent Australian trends. Urban Policy Res 25(1):133-153

Yigitcanlar T, Dur D, Dizdaroglu D (2014) Towards prosperous sustainable cities: a multiscalar urban sustainability assessment approach. Habitat Int. doi:10.1016/j.habitatint.2014.06. 033 
Zaman A (2013) Identification of waste management development drivers and potential emerging waste treatment technologies. Int J Environ Sci Technol 10(3):455-464

Zhao P (2010) Sustainable urban expansion and transportation in a growing megacity: consequences of urban sprawl for mobility on the urban fringe of Beijing. Habitat Int 34(2):236-243
Zhao P, Chapman R, Randal E, Howden-Chapman P (2013) Understanding resilient urban futures: a systemic modelling approach. Sustainability 5(1):3202-3223 